\title{
Shipping Damage or Problem
}

National Cancer Institute

\section{Source}

National Cancer Institute. Shipping Damage or Problem. NCI Thesaurus. Code C62925.

Problem associated with shipping damage or problem prior to the use of the device. 